\title{
Building a mini Electrical Substation through Project based Learning and analysing data using ANOVA
}

\section{YOGINI BHOSALE}

\section{Ing.Paed.IGIP}

Department of Electrical Engineering, Rajarambapu Institute of technology, Islampur. Tal Walva, DistSangli Maharashtra yogini.bhosale@ ritindia.edu

\begin{abstract}
Project-based learning (PBL) is a studentcentered pedagogy that involves a dynamic classroom approach, in which it believed that the students acquire a deeper knowledge through active exploration of real-world challenges and problems.For the same, with a set of prepared guidelines, third year B. Tech. Electrical Engineering students are asked to design a mini 'Electrical Substation'. These designs presented and evaluated by the internal and external examiners. Students are further motivated for deep study in substations. Total 18 groups of students worked on substation design project with 18 parts of Electrical Substation. This activity not only improved the learning index of the students but also improved course attainment, which mapped with program outcomes.
\end{abstract}

Keywords: Mini Electrical Substation, CPI, CO-PO attainment, ANOVA, SPSS

\section{INTRODUCTION}

Millennial learners are very much active and eager to find new things. To feed their intellectual brain, the design problems proposed. Few students always avoid participating in such activities and do not take lead. It is necessary to create same platform to all the students to show their skills. Student lead conference gives such platform. The activity was well planned and discussed with the students prior to the semester. It is lengthy activity and needs preparation. All the students of T.Y. B. Tech Electrical Engineering program had participated in this activity under the course 'Switchgear and Protection'. This course has wide scope for such competitions. Students are very much familiar with the electric failures, such as electric shock, short circuits, open circuits, overloading etc. They are also acquainted with fuse, MCB, energy meters, relays etc. This activity takes them from known to unknown and then finds the solutions [1]. Students are asked to form groups. These groups have done market survey for available equipments and their
cost.All groups have designed the single line diagram with available equipments. Students were very enthusiastic and creative in designing the scheme. One of the constraints is the scheme should not be similar within the groups. Rubrics formed by the course instructor for the evaluation of market survey and design schemes. Such as active participation, creativity, presentation, $\mathrm{Q}$ and $\mathrm{A}$, idea, parameter selection etc. Student's performance is measured and course attainment is calculated. Program outcomes mapped with it [1]

\section{METHODOLOGY}

The complete activity planned and divided in some stages.

Stage 1:- 'Project based learning', had discussed with the students witha set of guidelines. Students formed groups as per their choice. Heterogeneous 18 groups formed.

Group Formation: This course had offered to the students in third year B. Tech. Their average score of previous years in percentage calculated and arranged in ascending order. Group of 18 students formed. Strength of the class was $72(18 * 4=72)$. One student from each group (from 18 students) had selected sequentially and made another group of four students. Now, this group contains four students of different merit order possessing different skills. Such 18 groups formed. This is discussed in detail in fig no. 1 showing the grades of the students, fig. no.2 showing the arrangement in ascending order and fig. no. 3 showing the group formation.

Stage 2:- These groups had selected their role and equipment or part of substation to be designed. It is shown in Fig. no.4. All were undergone market survey. Students searched for the electrical equipments required in substation in the market with its specifications and cost. For cost reduction, few 
equipments have been designed by respective groups. Course contents haddelivered in the class in this duration.

\begin{tabular}{|c|c|c|c|c|c|c|c|}
\hline & PI & Ill & CPI & oll & CPI & Roll & \\
\hline 150 & 3 & 08018 & .05 & 180 & 6.34 & ר:0 & 3. \\
\hline 1508052 & 3 & 08019 & 7.58 & 608040 & & 608060 & .8 \\
\hline 1601045 & 6 & 08020 & 5.47 & 41 & & 0806 & \\
\hline & 2 & 08021 & 7.89 & 308042 & 7. & 60806 & \\
\hline 16 & 6 & 08022 & & 08043 & & 308063 & .55 \\
\hline 1608 & 7.03 & 608023 & .3 & 608044 & 8. & 58 & 6.0 \\
\hline 160 & 4 & 08024 & 4.62 & 08045 & 7. & 758002 & 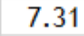 \\
\hline 16 & 7.5 & 08025 & & 08046 & 6. & 58004 & 7. \\
\hline 16 & 6 & 608026 & .09 & 08047 & 7. & 58005 & 7. \\
\hline 16 & 6 & 608027 & 8 & 08048 & 6. & 8006 & 8.1 \\
\hline & & 08028 & $8 . C$ & 49 & & 107 & 5. \\
\hline 1608010 & 7. & 08029 & 6.86 & 08051 & & 8009 & 7. \\
\hline 16 & & 608031 & 6 & 608052 & 5. & 3010 & 6. \\
\hline & & 608032 & 5 & 08054 & & 1758011 & 3.58 \\
\hline 16 & 5 & 1608033 & 7.42 & 608055 & 6.61 & 1758012 & 4.19 \\
\hline & & 08036 & & 08056 & & 758013 & 4. \\
\hline & & & & & & 14 & 6.7 \\
\hline 1608017 & 7.24 & 1608038 & 1.35 & 1608058 & 8.08 & 175801 & . \\
\hline
\end{tabular}

Fig. No.1- grades of the students

Above figure no. 1 shows the previous year CPI (Cumulative Performance Index) of the students of batch 2018-19.

\begin{tabular}{lc|cccccc}
1758011 & 3.58 & 1608014 & 5.99 & 1608048 & 6.92 & 1608019 & 7.58 \\
1608059 & 3.77 & 1608002 & 6.01 & 1608015 & 6.93 & 1608006 & 7.59 \\
1508046 & 3.84 & 1758001 & 6.05 & 1608007 & 6.99 & 1608009 & 7.59 \\
1508052 & 3.96 & 1608023 & 6.3 & 1608004 & 7.03 & 1608040 & 7.65 \\
1758012 & 4.19 & 1608025 & 6.3 & 1608056 & 7.05 & 1758004 & 7.66 \\
1758013 & 4.34 & 1608039 & 6.34 & 1608057 & 7.11 & 1608045 & 7.7 \\
1608001 & 4.59 & 1608049 & 6.57 & 1608043 & 7.16 & 1608041 & 7.73 \\
1608016 & 4.62 & 1608063 & 6.59 & 1608017 & 7.24 & 1608021 & 7.89 \\
1608024 & 4.62 & 1608055 & 6.61 & 1608010 & 7.27 & 1758005 & 7.91 \\
1608005 & 4.7 & 1601045 & 6.65 & 1758002 & 7.31 & 1608047 & 7.97 \\
1608026 & 5.09 & 1758010 & 6.65 & 1608012 & 7.32 & 1608028 & 8.03 \\
1608061 & 5.3 & 1608046 & 6.68 & 1608032 & 7.35 & 1608037 & 8.04 \\
1758007 & 5.39 & 1608051 & 6.74 & 1608038 & 7.35 & 1608018 & 8.05 \\
1608020 & 5.47 & 1758014 & 6.76 & 1608042 & 7.35 & 1608054 & 8.05 \\
1608060 & 5.8 & 1608022 & 6.8 & 1758009 & 7.39 & 1608058 & 8.08 \\
1608062 & 5.8 & 1608031 & 6.81 & 1608033 & 7.42 & 1608027 & 8.19 \\
1758015 & 5.8 & 1608008 & 6.84 & 1608013 & 7.46 & 1758006 & 8.19 \\
1608052 & 5.81 & 1608029 & 6.86 & 1608036 & 7.50 & 1608044 & 8.46
\end{tabular}

Fig No. 2- showing ascending order of CPI

Above figure no.2 shows an ascending order of CPI. This distribution is shown by using different color codes. Further, one student from each column is picked to form "Group".

\begin{tabular}{|c|c|c|c|c|}
\hline GROUP 1 & 1758011 & 1608014 & 1608048 & 1608019 \\
\hline GROUP 2 & 1608059 & 1608002 & 1608015 & 1608006 \\
\hline GROUP 3 & 1508046 & 1758001 & 1608007 & 1608009 \\
\hline GROUP 4 & 1508052 & 1608023 & 1608004 & 1608040 \\
\hline GROUP 5 & 1758012 & 1608025 & 1608056 & 1758004 \\
\hline GROUP 6 & 1758013 & 1608039 & 1608057 & 1608045 \\
\hline GROUP 7 & 1608001 & 1608049 & 1608043 & 1608041 \\
\hline GROUP 8 & 1608016 & 1608063 & 1608017 & 1608021 \\
\hline GROUP 9 & 1608024 & 1608055 & 1608010 & 1758005 \\
\hline GROUP 10 & 1608005 & 1601045 & 1758002 & 1608047 \\
\hline GROUP 11 & 1608026 & 1758010 & 1608012 & 1608028 \\
\hline GROUP 12 & 1608061 & 1608046 & 1608032 & 1608037 \\
\hline GROUP 13 & 1758007 & 1608051 & 1608038 & 1608018 \\
\hline GROUP 14 & 1608020 & 1758014 & 1608042 & 1608054 \\
\hline GROUP 15 & 1608060 & 1608022 & 1758009 & 1608058 \\
\hline GROUP 16 & 1608062 & 1608031 & 1608033 & 1608027 \\
\hline GROUP 17 & 1758015 & 1608008 & 1608013 & 1758006 \\
\hline GROUP 18 & 1608052 & 1608029 & 1608036 & 1608044 \\
\hline
\end{tabular}

Fig. No.3-“Group Formation”

Above figure no. 3 shows the group formation.

All groups have selected equipment to be designed in their group.

\begin{tabular}{|l|l|l|l|l|l|}
\hline GROUP 1 & Bus bar & GROUP 7 & $\begin{array}{l}\text { Current } \\
\text { Transformer }\end{array}$ & GROUP 13 & $\begin{array}{l}\text { Agricultural } \\
\text { load }\end{array}$ \\
\hline GROUP 2 & Poles & GROUP 8 & $\begin{array}{l}\text { voltage } \\
\text { Transformer }\end{array}$ & GROUP 14 & $\begin{array}{l}\text { Lightening } \\
\text { arrester }\end{array}$ \\
\hline GROUP 3 & insulators & GROUP 9 & $\begin{array}{l}\text { Circuit } \\
\text { breakers }\end{array}$ & GROUP 15 & $\begin{array}{l}\text { capacitor } \\
\text { bank }\end{array}$ \\
\hline GROUP 4 & earhing & GROUP 10 & Relays & GROUP 16 & Fencing \\
\hline GROUP 5 & $\begin{array}{l}\text { Residential } \\
\text { load }\end{array}$ & GROUP 11 & Switches & GROUP 17 & Panel board \\
\hline $\begin{array}{l}\text { GROUP 6 } \\
\text { Distribution } \\
\text { Transformer }\end{array}$ & GROUP 12 & Fuses & GROUP 18 & isolator \\
\hline
\end{tabular}

Fig No.4- Distribution of equipments

Stage 3:- Fig no.5 shows that students visited nearby substation $(33 \mathrm{kV} / 11 \mathrm{kV})$. They observed the substation and studied the same for their own substation design. As the students were designing for real solution, all the ratings must be dropped down. All groups designed the required specifications for substation. 440V/230V substation specifications were fixed. 


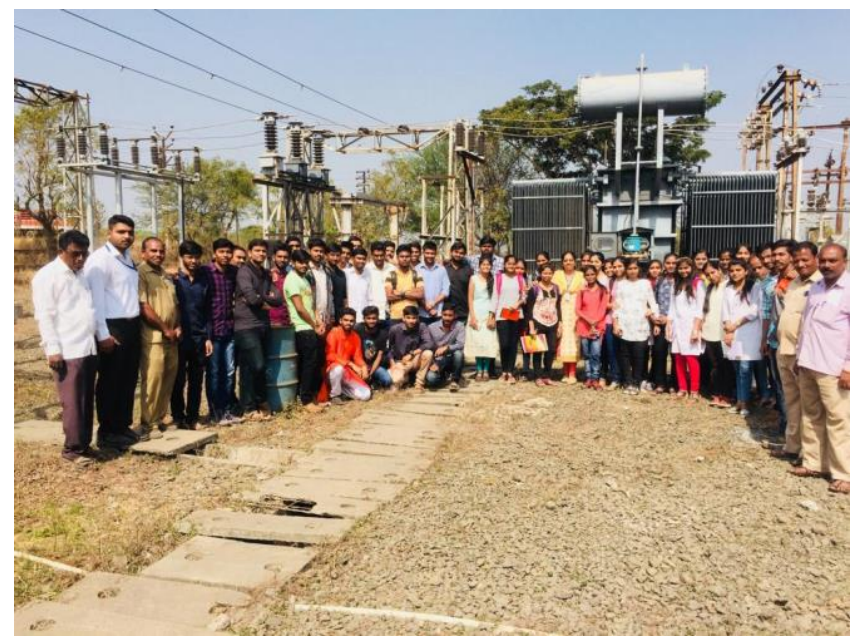

Fig no. 5- 33kV/11kV distribution substation visit

Stage 4:- All 18 groups had drawn single line diagram for substation. One single line diagram is commonly approved. Each group designed respective part of substation and tasted the system. Once all designs are verified and tasted, the actual building of substation is started.

Stage 5:- Students along with the course instructor selected one place, free space near to RIT college power house.The necessary, major cost equipments are provided by Electrical maintenance department and electrical engineering department. Fig no. 5 shows that the students are taking measurements for substation design

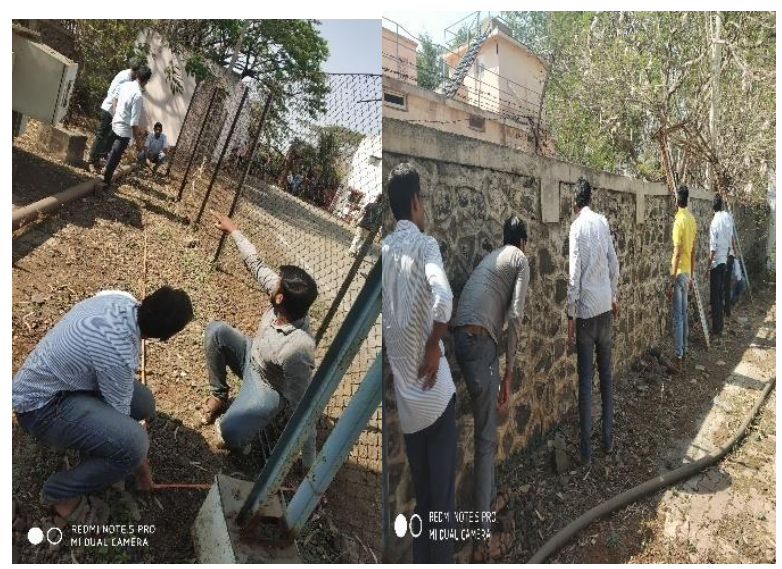

Fig. No. 5-Taking measurements for substation building

Stage 6:- Students marks are collected from examiners and course attainment is calculated. Program outcomes are also calculated and mapped. Fig.6 Shows the market survey for miniature circuit breaker. Students hold a poster on which construction, manufacturer (Siemens, L\&T, ABB, Havell's), specifications and cost are the four columns drawn.



Fig.no.6 Market survey for miniature circuit breaker

Following fig.no.7 shows that the students are demonstrating and explaining the substation to examiners


Fig. No. 7- Demonstration and Explanation

For the evaluation, rubrics were made and was given to the Examiners. Rubrics are also discussed with the students so students were too much enthusiastic 


\section{RESULTS}

After successfully completed these activity students are

1. acquainted with the electrical protection equipments used in the markets with its specifications and cost under 'Market Survey' activity and aware of the existing society related electrical problems

2. able to apply their knowledge to create solution scheme and implement skills to design protection scheme

3. improved their confidence, presentation and communication skills and ready to face next model competition

4. Course outcomes: - At the end of this course students will be able to

1. Explain fundamentals of different power system components

2. Classify and explain the operation of circuit breakers and relays

3. Discuss distance protection schemes

4. Determine the causes, effects and protective schemes for over-voltage and over-current relay.

5. Describe different faults and devise protection schemes for generator and transformer

5. These course outcomes are mapped with activities conducted throughout the semester for switchgear and protection subject

Table No.1 : Mapping of activities with course outcomes

\begin{tabular}{|c|c|c|c|c|c|}
\hline Activities & $\nabla$ &  & 0 &  & $\hat{0}$ \\
\hline Group formation and teamwork & & $\sqrt{ }$ & $\sqrt{ }$ & & \\
\hline Market survey & $\sqrt{ }$ & $\sqrt{ }$ & $\sqrt{ }$ & $\sqrt{ }$ & \\
\hline Poster Presentation & & $\sqrt{ }$ & $\sqrt{ }$ & $\sqrt{ }$ & $\sqrt{ }$ \\
\hline Design solution & $\sqrt{ }$ & $\sqrt{ }$ & $\sqrt{ }$ & $\sqrt{ }$ & $\sqrt{ }$ \\
\hline Final competition & $\sqrt{ }$ & $\sqrt{ }$ & $\sqrt{ }$ & $\sqrt{ }$ & $\sqrt{ }$ \\
\hline
\end{tabular}

6. Attainments are calculated

Attainments are calculated by direct and indirect method. Direct method - Students marks from InSemester Evaluation and final demonstration. [2]

Indirect Method- Student's Feedback[2]

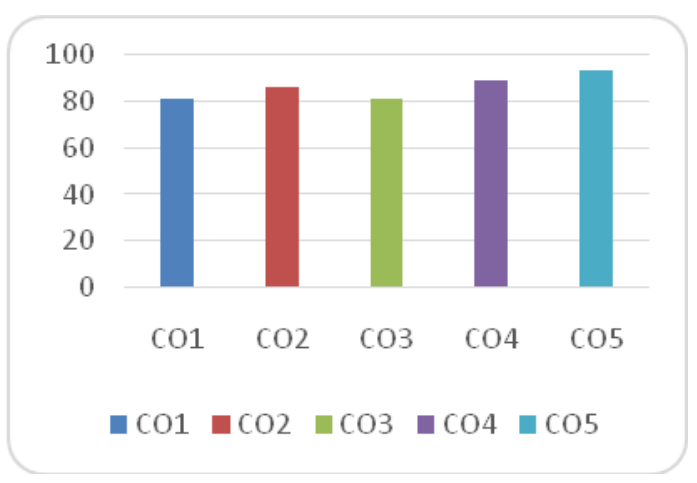

Graph No. 1: Attainment of course outcomes in percentage

From the above results it is seen that the $\mathrm{CO} 5$ is mapped excellently which is about designing the protection scheme.

7. Program outcomes are mapped



Graph No. 2: Attainment of program outcomes in percentage

It is also observed that the $\mathrm{PO}(\mathrm{g})$ is achieved excellently from this course, which helps them in technical interviews with raised confidence

\section{PROGRAM OUTCOMES OF ELECTRICAL ENGINEERING DEPARTMENT}

Table No. 2 : Program outcomes of Electrical Engineering Department

\begin{tabular}{|l|l|}
\hline a & $\begin{array}{l}\text { Apply knowledge of mathematics, science, and } \\
\text { electrical engineering. }\end{array}$ \\
\hline b & $\begin{array}{l}\text { Design and conduct experiments, as well as to analyze } \\
\text { and interpret data. }\end{array}$ \\
\hline c & $\begin{array}{l}\text { Design a system, components or process to meet } \\
\text { desired needs within realistic constraints such as } \\
\text { economic, environmental, social, political, ethical, }\end{array}$ \\
\hline
\end{tabular}




\begin{tabular}{|l|l|}
\hline & health and safety, manufacturability and sustainability \\
\hline $\mathrm{d}$ & Function on multidisciplinary teams. \\
\hline $\mathrm{e}$ & $\begin{array}{l}\text { Identify, formulate, and solve electrical engineering } \\
\text { problems }\end{array}$ \\
\hline $\mathrm{f}$ & Demonstrate professional and ethical responsibility \\
\hline $\mathrm{g}$ & Communicate effectively at work. \\
\hline $\mathrm{h}$ & $\begin{array}{l}\text { Understand the impact of electrical engineering } \\
\text { solutions in global, economic, environmental, and } \\
\text { societal context }\end{array}$ \\
\hline $\mathrm{i}$ & Engage in life-long learning \\
\hline $\mathrm{j}$ & $\begin{array}{l}\text { Use the techniques, skills, and modern engineering } \\
\text { tools necessary for engineering practice. }\end{array}$ \\
\hline $\mathrm{k}$ & $\begin{array}{l}\text { Apply the knowledge to evaluate contemporary issues } \\
\text { with project and finance management skills. }\end{array}$ \\
\hline
\end{tabular}

\section{DISCUSSION}

For ANOVA test case, the group isdivided in 4 columns. Group A, Group B, Group C and Group D

Each group has undergone separate task with its own learning activity. Group A was considering the students scored higher in previous exams. These students are asked to design the selected object with their respective team under conventional teaching learning, Group B had selected the suitable equipment for substation (Brainstorming). Group $\mathrm{C}$ had done the market survey for the cost effective elements with proper specification (Group Discussion).Group Ddecided to visit the site for optimal placement of the equipments (PBL).

Table No. 3 : Groups formation for ANOVA

$\begin{array}{lcccc} & \text { A } & \text { B } & \text { C } & \text { D } \\ \text { GROUP 1 } & 1758011 & 1608014 & 1608048 & 1608019 \\ \text { GROUP 2 } & 1608059 & 1608002 & 1608015 & 1608006 \\ \text { GROUP 3 } & 1508046 & 1758001 & 1608007 & 1608009 \\ \text { GROUP 4 } & 1508052 & 1608023 & 1608004 & 1608040 \\ \text { GROUP 5 } & 1758012 & 1608025 & 1608056 & 1758004 \\ \text { GROUP 6 } & 1758013 & 1608039 & 1608057 & 1608045 \\ \text { GROUP 7 } & 1608001 & 1608049 & 1608043 & 1608041 \\ \text { GROUP 8 } & 1608016 & 1608063 & 1608017 & 1608021 \\ \text { GROUP 9 } & 1608024 & 1608055 & 1608010 & 1758005 \\ \text { GROUP 10 } & 1608005 & 1601045 & 1758002 & 1608047 \\ \text { GROUP 11 } & 1608026 & 1758010 & 1608012 & 1608028 \\ \text { GROUP 12 } & 1608061 & 1608046 & 1608032 & 1608037 \\ \text { GROUP 13 } & 1758007 & 1608051 & 1608038 & 1608018 \\ \text { GROUP 14 } & 1608020 & 1758014 & 1608042 & 1608054 \\ \text { GROUP 15 } & 1608060 & 1608022 & 1758009 & 1608058 \\ \text { GROUP 16 } & 1608062 & 1608031 & 1608033 & 1608027 \\ \text { GROUP 17 } & 1758015 & 1608008 & 1608013 & 1758006 \\ \text { GROUP 18 } & 1608052 & 1608029 & 1608036 & 1608044\end{array}$

'Teamwork' and 'coordination' are the most essential part of building a substation.

Null Hypothesis: All activities are equally good.

Alternative Hypothesis: At least two are not equally good

Let's define $\mathrm{N}=\sum \mathrm{Ni}$ where $\mathrm{Ni}=\mathrm{N}_{\mathrm{A}}, \mathrm{N}_{\mathrm{B}}, \mathrm{N}_{\mathrm{C}}, \mathrm{N}_{\mathrm{D}}$, (specimen). $\mathrm{N}_{\mathrm{A}=} \mathrm{N}_{\mathrm{B}=} \mathrm{N}_{\mathrm{C}=} \mathrm{N}_{\mathrm{D}=18 .} \mathrm{N}=\sum \mathrm{Ni}=72$

Calculations: $\mathrm{Df}=$ Degree of freedom

Df $f_{\text {between }}=$ No. of conditions $(\mathrm{k}=4)-1=3 ; \mathrm{Df}_{\mathrm{within}}=$ Total No. of observations $(\mathrm{N}=72)-(\mathrm{k}=4)=\mathbf{6 8} ; \mathrm{Df}_{\text {total }}=68+3=71$;

Evaluation of PBL-ISE-Marks (Max =20)

Table No. 4: Marks of students

\begin{tabular}{ccccc} 
& A & B & C & D \\
GROUP 1 & 12 & 14 & 20 & 16 \\
GROUP 2 & 14 & 17 & 18 & 17 \\
GROUP 3 & 15 & 17 & 14 & 19 \\
GROUP 4 & 14 & 17 & 18 & 15 \\
GROUP 5 & 17 & 18 & 18 & 19 \\
GROUP 6 & 13 & 14 & 15 & 17 \\
GROUP 7 & 17 & 17 & 17 & 17 \\
GROUP 8 & 15 & 15 & 19 & 16 \\
GROUP 9 & 13 & 16 & 17 & 19 \\
GROUP 10 & 13 & 15 & 17 & 19 \\
GROUP 11 & 18 & 12 & 17 & 14 \\
GROUP 12 & 15 & 14 & 14 & 19 \\
GROUP 13 & 17 & 18 & 12 & 15 \\
GROUP 14 & 18 & 17 & 17 & 14 \\
GROUP 15 & 19 & 16 & 19 & 17 \\
GROUP 16 & 16 & 16 & 16 & 18 \\
GROUP 17 & 17 & 18 & 16 & 16 \\
GROUP 18 & 13 & 18 & 18 & 19 \\
Total(T1,T2,T3,T4) & $\mathbf{2 7 6}$ & $\mathbf{2 8 9}$ & $\mathbf{3 0 2}$ & $\mathbf{3 0 6}$ \\
Square & $\mathbf{7 6 1 7 6}$ & $\mathbf{8 3 5 2 1}$ & $\mathbf{9 1 2 0 4}$ & $\mathbf{9 3 6 3 6}$ \\
\hline
\end{tabular}

Raw S. S. = 19391 ; Correction factor $(\mathrm{CF})=\mathrm{G}^{2} / \mathrm{n}=$ $(1173)^{2} / 72=19110.125$; Total S S $=$ RSS $-\mathrm{CF}=19391-$ $19110=281$; S.S. due to treatments $=\mathrm{T}_{1}^{2} / \mathrm{N}_{\mathrm{A}}+\mathrm{T}^{2} / \mathrm{N}_{\mathrm{B}}+$ $\mathrm{T} 3^{2} / \mathrm{N}_{\mathrm{C}}+\mathrm{T} 4^{2} / \mathrm{N}_{\mathrm{D}}-\mathrm{CF}=30.875$

Error SS $=$ Total S S $-\mathrm{S} \mathrm{S}$ due to treatment $=250.125$

Table No. 5: Finding Variance

\begin{tabular}{|l|l|l|l|l|}
\hline $\begin{array}{l}\text { Source of } \\
\text { Variation }\end{array}$ & S. S. & d.f. & MSS & $\begin{array}{l}\text { Variance } \\
\text { Ratio }\end{array}$ \\
\hline Treatments & 30.875 & $4-1=3$ & 10.29 & $\mathrm{~F}=2.797$ \\
\hline Error & 250.125 & $\begin{array}{l}71-3= \\
68\end{array}$ & 3.678 & \\
\hline Total & 281 & $\begin{array}{l}72-1= \\
71\end{array}$ & & \\
\hline
\end{tabular}

$(\alpha=0.05)$ Table No. 6 : Table to find critical value 


\begin{tabular}{l|ll|l|l}
\hline 65 & 3.99 & 3.14 & 2.75 & 2.51 \\
66 & 3.99 & 3.14 & 2.74 & 2.51 \\
67 & 3.98 & 3.13 & 2.74 & 2.51 \\
\hline 68 & 3.98 & 3.13 & 2.74 & 2.51 \\
\hline 69 & 3.98 & 3.13 & 2.74 & 2.51 \\
70 & 3.98 & 3.13 & 2.74 & 2.50 \\
71 & 3.98 & 3.13 & 2.73 & 2.50 \\
72 & 3.97 & 3.12 & 2.73 & 2.50
\end{tabular}

The calculated value of $F=2.79$ is more than the tabulated value of $F=2.74$. (This result through SPSS is shown in table no.7). Hence, we reject null hypothesis and conclude that not all methods are equally good. An alternative hypothesis accepted which says that there is difference in learning types. To find the best method, the mean of all groups are calculated.

Group $\mathrm{A}=15.33$; Group $\mathrm{B}=16.05$; Group $\mathrm{C}=16.77$; Group $\mathrm{D}=17$. The mean of Group ' $\mathrm{D}$ ' is more. It indicates that the students working on site learnt more.(Result through SPSS is shown in table no. 9)

Table No. 7: ANOVA results in SPSS

\begin{tabular}{|c|c|c|c|c|c|}
\hline \multicolumn{6}{|c|}{ ANOVA } \\
\hline & $\begin{array}{l}\text { Sum of } \\
\text { Squares }\end{array}$ & $d f$ & Mean Square & $F$ & Sig. \\
\hline Between Groups & 30.819 & 3 & 10.273 & 2.794 & .047 \\
\hline Within Groups & 250.056 & 68 & 3.677 & & \\
\hline Total & 280.875 & 71 & & & \\
\hline
\end{tabular}

Table No. 8: Results for Post Hoc Tests Post Hoc Tests

\begin{tabular}{|c|c|c|c|c|c|c|}
\hline \multicolumn{7}{|c|}{ Multiple Comparisons } \\
\hline \multicolumn{7}{|c|}{ DependentVariable: Learning_Type } \\
\hline \multirow[b]{2}{*}{ (I) Group } & \multirow[b]{2}{*}{ (J) Group } & \multirow{2}{*}{$\begin{array}{c}\text { Mean } \\
\text { Difference (I- } \\
\mathrm{J})\end{array}$} & \multirow[b]{2}{*}{ Std. Error } & \multirow[b]{2}{*}{ Sig. } & \multicolumn{2}{|c|}{$95 \%$ Confidence Interval } \\
\hline & & & & & Lower Bound & Upper Bound \\
\hline \multirow[t]{3}{*}{ A } & B & -.722 & 639 & .672 & -2.41 & .96 \\
\hline & c & -1.444 & 639 & .118 & -3.13 & .24 \\
\hline & D & -1.667 & 639 & .053 & -3.35 & .02 \\
\hline \multirow[t]{3}{*}{ B } & A & .722 & 639 & 672 & -.96 & 2.41 \\
\hline & c & -.722 & 639 & 672 & -2.41 & .96 \\
\hline & D & -.944 & 639 & .457 & -2.63 & .74 \\
\hline \multirow[t]{3}{*}{ c } & A & 1.444 & 639 & .118 & -.24 & 3.13 \\
\hline & B & .722 & 639 & .672 & -.96 & 2.41 \\
\hline & D & -.222 & .639 & .985 & -1.91 & 1.46 \\
\hline \multirow[t]{3}{*}{ D } & A & 1.667 & .639 & .053 & -.02 & 3.35 \\
\hline & B & .944 & .639 & .457 & -.74 & 2.63 \\
\hline & c & .222 & 639 & 985 & -1.46 & 1.91 \\
\hline
\end{tabular}

Above table, no. 8 shows the results of Post Hoc Tests. Each group ( I) compared with the remaining groups (J). Mean difference for first case is calculated as Mean of Group A 15.33 - Mean of Group B $16.05=-0.72$. This column gives all positive values in last comparison. This comparison shows that Group D has better results than A, B and C. Similarly, other values calculated for other groups.
Table No. 9: Results for Homogeneous Test Homogeneous Subsets

\begin{tabular}{|c|c|c|}
\hline \multicolumn{3}{|c|}{ Learning_Type } \\
\hline Group & $\mathrm{N}$ & $\begin{array}{c}\text { Subset for } \\
\text { alpha }=0.05 \\
1\end{array}$ \\
\hline A & 18 & 15.33 \\
\hline B & 18 & 16.06 \\
\hline C & 18 & 16.78 \\
\hline D & 18 & 17.00 \\
\hline Sig. & & .053 \\
\hline \multicolumn{3}{|c|}{$\begin{array}{l}\text { Means for groups in homogeneous } \\
\text { subsets are displayed. }\end{array}$} \\
\hline a. U & $\begin{array}{l}\text { armo } \\
\text { Size }\end{array}$ & $\begin{array}{l}\text { ean } \\
000 .\end{array}$ \\
\hline
\end{tabular}

\section{CONCLUSION}

The main objective of this activity is satisfied. All thestudents have participated with the same interest and enthusiasm. They got the platform to demonstrate their skills and creativity. Students developed simulation model for high ratings and hardware models for lower ratings. This shows their improved creativity and design ability. All the students have learnt from each other as every group developed a different protection scheme. Groups A,B,C,D differentiated by the student previous score. Group D with fewer score performed better through PBL and secured good marks in exam. ANOVA test is helpful for analysing this data. This data analysis verified and compared through IBM SPSS tool.

\section{ACKNOWLEDGEMENT}

I sincerely express my deep gratitude towards IIEECP coordinators, RIT management and my colleagues for their continuous support and motivation. I thank to the reviewers who guided me indirectly through their remarks on my extended abstract.

\section{REFERENCES}

[1] Yogini Bhosale, "Design and Implementation of Electrical Protection Scheme through Student Lead Conference (An Active Learning Tool)", $6^{\text {th }}$ international conference on transformation in engineering education, ICTIEE2019

[2] Yogini Bhosale, "Continuous assessment technique of industry in plant training through activities for outcome based education", $5^{\text {th }}$ international conference on transformation in engineering education, ICTIEE2018

[3] http://www.discoveringstatistics.com/repositoryancova.pdf

[4] MonchaiTiantong, SumaleeSiksen, "The Online Projectbased Learning Model Based on Student's Multiple Intelligence", International Journal of Humanities and Social Science, Vol. 3 No. 7; April 2013

[5] IBM SPSS tool

[6] "Fundamentals of Statistics", book by S. C. Gupta, Himalaya Publishing House, $7^{\text {th }}$ edition. 